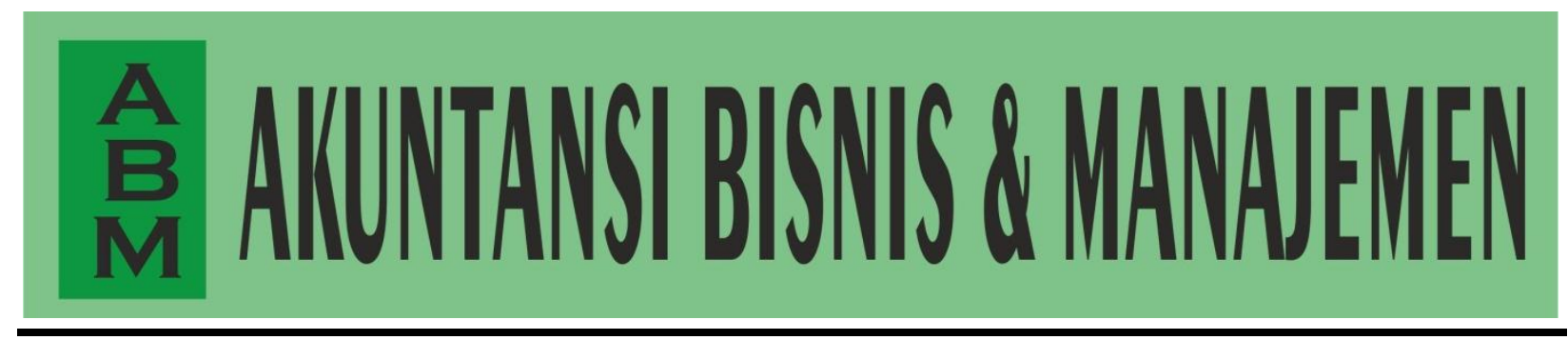

\title{
LOKASI USAHA DAN FASILITAS PELAYANAN SEBAGAI DETERMINAN KEPUTUSAN PEMBELIAN
}

\author{
Suci Putri Lestari'1), Arga Sutrisna2), Muhammad Mafazi ${ }^{3)}$ \\ 1,2,3) Universitas Perjuangan Tasikmalaya \\ Jl. Peta No. 177 Kahuripan, Kec. Tawang Kota Tasikmalaya 46115 Indonesia
}

E-Mail: Suciputri@unper.ac.id

DOI: https://doi.org/10.35606/jabm.v27i2.687

\section{Akuntansi Bisnis dan \\ Manajemen (ABM),}

Vol. 27

No. 02

Halaman 69-78

Bulan Oktober, Tahun 2020

ISSN 0854-4190

E-ISSN 2685-3965

\section{Informasi Artikel}

Tanggal Masuk:

15 Juni 2020

Tanggal Revisi:

25 September 2020

Tanggal Diterima:

20 Oktober 2020

\begin{abstract}
The purpose of this study is to examine and analyze the effect of business location and facilities on hotel consumer decisions. This study involved 100 respondents as a sample who is hotel service users. Hypothesis testing uses multiple regressions. The research results explain that access and visibility contribute significantly as indicators of strategic business locations. The architecture of the placement of the facilities, the interior, the completeness of the facilities and the air circulation are important indicators of the service facility variables. The research results prove that the business location and facilities have a significant effect on purchasing decisions.
\end{abstract}

Keywords: business location; service facilities; purchasing decisions; hospitality

\section{Abstrak}

Tujuan dari penelitian ini adalah untuk menguji dan menganalisis pengaruh lokasi bisnis dan fasilitas terhadap keputusan konsumen hotel. Penelitian ini melibatkan 100 responden sebagai sampel yang merupakan pengguna jasa hotel. Pengujian hipotesis menggunakan regresi berganda. Hasil penelitian menjelaskan bahwa akses dan visibilitas berkontribusi signifikan sebagai indikator lokasi bisnis yang strategis. Arsitektur penempatan fasilitas, interior, kelengkapan fasilitas dan sirkulasi udara merupakan indikator penting dari variabel fasilitas pelayanan. Hasil penelitian membuktikan bahwa lokasi usaha dan fasilitas berpengaruh signifikan terhadap keputusan pembelian.

Keywords: lokasi usaha; fasilitas pelayanan; keputusan pembelian; perhotelan 


\section{PENDAHULUAN}

Perhotelan adalah industri jasa yang menggabungkan usahanya antara produk dan layanan. Produk yang dijual oleh industri perhotelan kepada pengunjung adalah layanan dan kelengkapan fasilitasnya. Layanan merupakan faktor utama dalam bisnis perhotelan, karena seenak apa pun makanan yang disajikan jika layanan yang diberikan buruk maka sajian itu menjadi tidak berarti (Supriyanto \& Taali, 2018). Pada awalnya hotel hanya difungsikan sebagai tempat menginap bagi para pengunjung yang melakukan perjalanan bisnis atau wisata, namun seiring perkembangan zaman dan kebutuhan, fungsi hotel bertambah banyak seperti untuk pesta, rapat, seminar, dan kegiatan lain yang membutuhkan tempat untuk diskusi dan menginap. Salah satu fungsi hotel yang banyak dimanfaatkan oleh masyarakat adalah paket untuk pertemuan (Fauzan \& Setiyorini, 2011). Hal ini menurut mereka karena persaingan antar hotel cukup tinggi, sehingga manajemen hotel akan berlomba-lomba untuk menaikkan tingkat kunjungan ke hotelnya.

Kunjungan hotel yang sejak tahun 2008 - 2019 selalu meningkat, mulai awal tahun 2020 sampai bulan Mei menurun tajam (BPS, 2020). Hal ini merupakan dampak diberlakukannya PSBB${ }^{1}$ di berbagai wilayah akibat pandemi covid-19. Dampak PSBB ini sangat dirasakan pada sektor pariwisata yang menurut Wishnutama (Kepala Badan Pariwisata dan Ekonomi Kreatif) terjadi tidak saja di Indonesia tetapi di seluruh dunia, oleh karena itu beliau bertekad untuk bekerja sama dengan semua pihak meningkatkan kembali sektor pariwisata pasca pandemi (Benke, 2020). Turunnya kunjungan wisata ke berbagai daerah/negara otomatis berdampak pada industri perhotelan. Hal ini wajar karena adanya PSBB telah membatasi berbagai pihak untuk menjaga jarak yang artinya rapat, seminar, dan kegiatan yang menghimpun orang banyak dibatasi. Ini berarti pula bahwa kegiatan-kegiatan yang biasanya diselenggarakan di hotel beralih melalui kegiatan yang dilakukan secara daring. Dengan demikian kondisi ini menurunkan tingkat hunian kamar (occupancy) hotel.

Tingkat hunian kamar menurut Juhari (2016) sangat dipengaruhi oleh harga yang ditawarkan meskipun masih ada faktor lain yang juga ikut memengaruhinya. Caesari, Nugraha, and Prabawani (2015) menyampaikan bahwa yang memengaruhi orang menginap di hotel selain harga adalah fasilitas, lokasi, dan kualitas pelayanan. Menurut mereka harga tidak terlalu berpengaruh karena tarif yang ditetapkan telah disesuaikan dengan harga pasar dan layanan yang diberikan. Sementara itu, Chandra and Tielung (2015) yang meneliti tentang Pengaruh Kualitas Pelayanan, Promosi, dan Lokasi terhadap Keputusan menggunakan Hotel Baliem Pilamo hasil yang diperoleh adalah kualitas layanan dan promosi berpengaruh secara positif dan signifikan, sedangkan promosi berpengaruh positif tetapi tidak signifikan. Penelitian lain yang dilakukan Lempoy, Mandey, and Loindong (2015) Harga, Lokasi, dan Fasilitas berpengaruh secara signifikan terhadap pengambilan keputusan.

Berdasarkan penelitian terdahulu yang diuraikan sebelumnya, peneliti ingin menguji kembali pengaruh lokasi dan fasilitas layanan pada obyek yang berbeda dari peneliti sebelumnya. Hal ini dilakukan karena menurut peneliti lokasi dan fasilitias layanan masih merupakan variabel penentu bagi konsumen untuk menginap di hotel. Penelitian ini

\footnotetext{
${ }^{1}$ PSBB $=$ Pembatasan Sosial Berskala Besar
} 
merupakan replikasi dari penelitian yang dilakukan oleh Lempoy et al. (2015) dengan obyek yang berbeda. Lempoy et.al meneliti di Wamena sedangkan peneliti melakukannya di hotel Asri Tasikmalaya.

Pemilihan Hotel Asri sebagai obyek penelitian dikarenakan Tasikmalaya merupakan pusat perekonomian di Wilayah Priangan Timur Jawa Barat. Lokasi hotel ini sangat strategis karena berdekatan dengan pusat bisnis dan industri. Lokasi ini juga banyak diincar para investor untuk mendirikan hotel mulai dari yang kelas menengah sampai hotel berbintang lima. Selain itu jika diperhatikan testimoni yang diberikan pengguna hotel yang dirilis dari berbagai website, hotel Asri termasuk pilihan konsumen karena berbagai kriteria penilaian yang dilakukan. Beberapa hasil penilaian pelanggan yang dilansir dari beberapa website menunjukkan hasil sebagai berikut.

- Reputasi mengagumkan, Fasilitas luar biasa di area property, Pelayanan luar biasa, dan Kebersihan luar biasa. Total nilai setelah dihitung rata-ratanya $=8.2$ dengan kriteria "Luar biasa" (Agoda);

- Kebersihan, Kenyamanan, Makanan, dan Lokasi, serta pelayanan yang dinilai sangat memuaskan oleh pelanggan sehingga diperoleh nilai 8.4 dengan kriteria "Mengesankan" (Traveloka);

- Penilaian harga yang tidak ada duanya, staff yang bisa menggunakan dua bahasa, pemesanan aman, dan pengelolaan pesanan online; total nilai 7.7 dengan kriteri "Baik". (Booking.com)

- Kenyamanan, Kebersihan, Pelayanan, Lokasi, Harga Kenyamanan, Kebersihan Pelayanan Lokasi Harga, total nilai = 9 dengan kriteri " Luar Biasa" (Pegipegi)

Berdasarkan uraian sebelumnya, maka penelitian ini dilakukan dengan tujuan untuk menguji dan menganalisis pengaruh lokasi bisnis dan fasilitas terhadap keputusan konsumen hotel

\section{KAJIAN PUSTAKA}

\section{Lokasi usaha sebagai aset strategis}

Lokasi yang diartikan sebagai tempat di mana suatu usaha dijalankan perlu mempertimbangkan beberapa hal, yaitu: (1) Terjangkau, artinya lokasi ini mudah dijangkau oleh sarana transportasi atau sering dilalui kendaraan umum dan pribadi; (2) Terlihat dengan jelas dari jarak pandang normal; (3) Lalu lintas yang berhubungan dengan tingkat kemacetan dan kepadatan jalan raya; (4) Tersedia tempat yang cukup luas dan memudahkan ekspansi di kemudian hari; serta (5) Lingkungan sekitar yang mendukung suatu produk untuk ditawarkan; persaingan, dan peraturan pemerintah (Tjiptono, 2014).

Lokasi yang strategis akan banyak diminati konsumen dalam mengambil keputusan, seperti yang disampaikan oleh Lempoy et al. (2015); Memah, Tumbel, and Rate (2015). Lebih lanjut dinyatakan oleh Memah et al. (2015), bahwa lokasi yang strategis dapat meningkatkan laba, karena dapat mengundang konsumen mengambil keputusan terhadap suatu produk yang ditawarkan. 


\section{Fasilitas pelayanan sektor jasa}

Fasilitas merupakan segala sesuatu yang bersifat peralatan fisik dan disediakan oleh pihak penjual jasa untuk mendukung kenyamanan konsumen (Kotler \& Amstrong, 2013). Dimensi fasilitas yang disampaikan Tjiptono (2014) meliputi, (1) Pertimbangan atau perencanaan parsial. (2) Perencanaan ruang yang meliputi arsitektur penempatan, interior, kelengkapan di dalam ruangan, dan desain aliran sirkulasi udara. (3) Perlengkapan atau perabotan, sebagai tanda penyambutan bagi konsumen, dan sebagai sarana pelindung barang berharga. (4) Pencahayaan yang disesuaikan sifat dan jenis aktivitas yang akan dilakukan dalam ruangan serta suasana yang diinginkan. (5) Warna yang dipilih dan dikaitkan dengan efek emosional yang akan didapat sehingga akan menimbulkan kesan rileks, meningkatkan efisiensi, serta mengurangi tingkat kecelakaan. (6) Pesan-pesan yang disampaikan secara grafis dan unsur pendukung.

Fasilitas yang disediakan oleh pihak pemberi jasa merupakan faktor penentu bagi seorang konsumen untuk mengambil keputusan. Hal ini sebagaimana yang diungkap dalam hasil penelitian Memah et al. (2015) yang menyatakan bahwa fasilitas berpengaruh positif terhadap keputusan konsumen dalam membeli rumah. Peningkatan kualitas dari sebuah fasilitas akan meningkatkan juga jumlah keputusan yang dibuat oleh konsumen, meskipun tidak signifikan. Senada dengan ini, Jusuf, Laela, and Sari (2018) juga mengungkapkan bahwa fasilitas berpengaruh secara signifikan terhadap keputusan pembelian. Menurut mereka fasilitas yang baik akan membentuk persepsi yang baik di mata konsumen, yang akhinya keputusan akan diambil oleh konsumen tersebut.

\section{Anteseden keputusan pembelian}

Keputusan pembelian yang dimaksud oleh Jusuf et al. (2018) adalah keputusan konsumen untuk menginap di Hotel Grand Dafam Bela Ternate. Keputusan pembelian menurut Lupiyoadi (2013) adalah semua aktivitas ekonomi yang hasilnya tidak merupakan produk dalam bentuk fisik atau konstruksi, yang biasanya dikonsumsi pada waktu yang sama pada waktu dihasilkan dan memberikan nilai tambah (seperti hiburan, kenyamanan, kesenangan dan kesehatan) atau pemecahan akan masalah yang dihadapi konsumen.

Dimensi keputusan pembelian menurut Kotler and Keller (2012) terdiri atas pilihan produk, pilihan merek, pilihan penyalur, waktu pembelian, jumlah pembelian, dan metode pembayaran. Seorang konsumen akan mengambil keputusan untuk membeli jika ada berbagai kriteria yang ditawarkan seperti yang diuraikan sebelumnya. Keputusan untuk membeli produk tertentu dengan jenis yang beragam mendorong konsumen untuk mempertimbangkan hal lainnya seperti merek, metode pembayaran, atau penyalur.

\section{Pengembangan Hipotesis}

Berdasarkan landasan teori, masalah penelitian dan penelitian terdahulu, maka hipotesis yang dikembangkan tampak pada gambar berikut ini. 


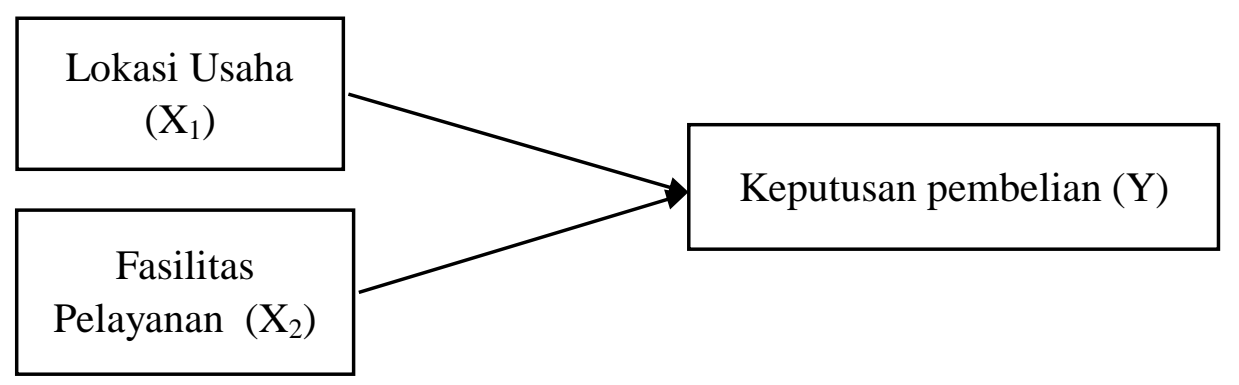

Gambar 1. Model Penelitian

Pemilihan lokasi yang tepat akan menjadi salah satu hal yang sangat berpengaruh terhadap proses pengambilan keputusan konsumen untuk menginap. Lokasi yang terjangkau dan strategis akan menjadi penentu bagi konsumen untuk mengambil keputusan (Caesari et al., 2015). Fasilitas juga merupakan unsur lainnya yang akan memengaruhi proses pengambilan keputusan bagi konsumen untuk menginap di hotel Asri Tasikmalaya. Ragam fasilitas yang disediakan oleh perusahaan, akan menyebabkan konsumen merasa kebutuhannya terpenuhi. Terpenuhinya kebutuhan tersebut, dapat berpengaruh dalam pengambilan keputusannya (Memah et al., 2015).

Fasilitas merupakan sumber daya fisik yang harus ada sebelum suatu jasa ditawarkan kepada konsumen (Tjiptono. 2014). Dengan demikian dapat ditarik kesimpulan jika perusahaan dapat memenuhi kebutuhan konsumen meliputi lokasi yang strategis dan fasilitas yang memadai, maka tidak akan sulit bagi konsumen untuk menentukan pilihannya (Permatasari \& Hadi, 2017). Berdasarkan uraian ini, maka hipotesis yang ditetapkan adalah,

H1 : Terdapat pengaruh Lokasi usaha terhadap keputusan pembelian

H2 : Terdapat pengaruh fasilitas pelayanan terhadap keputusan pembelian

\section{METODE PENELITIAN}

Penelitian ini termasuk kategori jenis korelasional, karena ditujukan untuk menguji dua atau lebih variabel (Duli, 2019, p. 7). Sampel yang digunakan sebanyak 100 orang pengguna jasa hotel dan diambil secara acak. Data dikumpulkan melalui kuesioner. Variabel yang diuji adala lokasi usaha (X1) dan pelayanan (X2), serta Keputusan Pembelian (Y)

Variabel lokasi usaha diukur dengan indikator: visibilitas, visibilitas, lalu lintas (traffic), tempat parkir, ekspansi, lingkungan, persaingan (lokasi pesaing) dan peraturan pemerintah. Variabel Fasilitas pelayanan diukur dengan indikator pertimbangan atau perencanaan parsial, perencanaan ruangan, perlengkapan atau perabotan, tata cahaya, warna, pesan-pesan yang disampaikan secara grafis dan unsur pendukung. Variabel keputusan pembelian diukur dengan indikator pilihan produk, pilihan merek,p ilihan penyalur, waktu penbelian, jumlah pembelian dan metode pembayaran. Analisis regresi digunakan untuk menguji validitas, reliabilitas, uji model (Rsquare), dan Uji signifikansi koefisien regresi. 


\section{HASIL DAN PEMBAHASAN}

Uji validitas dilakukan dengan cara menghitung korelasi dari masing-masing skor item pertanyaan dengan total item-item pertanyaan tersebut. Jika koefisien antara item pertanyaan dengan total item pertanyaan sama atau diatas 0,3 maka item pertanyaan tersebut dinyatakan valid. Berdasarkan tabel hasil uji validitas dinyatakan bahwa seluruh item pertanyaan dalam instrumen penelitian valid karena telah memenuhi kriteria. Hasil uji reliabilitas menunjukkan variabel lokasi (X1), Fasilitas (X2) dan Keputusan menginap (Y) memiliki nilai Cronbach Alpha lebih dari 0,6. sehingga disimpulkan memenuhi syarat reliabilitas yang baik.

\section{Tabel.1 Hasil Uji Reliabilitas}

\begin{tabular}{lccc}
\hline \multicolumn{1}{c}{ Variabel } & $\begin{array}{c}\text { Cronbach's } \\
\text { Alpha }\end{array}$ & $\begin{array}{c}\text { Standar } \\
\text { Reliabilitas }\end{array}$ & Keterangan \\
\hline Lokasi & 0,801 & 0,6 & Reliabel \\
Fasilitas & 0,899 & 0,6 & Reliabel \\
Keputusan Menginap & 0,872 & 0,6 & Reliabel \\
\hline
\end{tabular}

Hasil uji asumsi klasik menunjukkan data terdistribusi dengan normal, tidak terjadi multikolinearitas, tidak terjadi heteroskedastisitas, dan bebas autokorelasi.

Tabel 2. Nilai Korelasi dan Multikolinearitas

\begin{tabular}{lc}
\hline \multicolumn{1}{c}{ Variabel Penelitian } & Korelasi \\
\hline Lokasi $\left(\mathrm{X}_{1}\right)$ & 0,361 \\
Fasilitas $\left(\mathrm{X}_{2}\right)$ & 0,392 \\
\hline
\end{tabular}

Antar variabel independent tidak ada korelasi yang tinggi bahwa tidak ada variabel yang memiliki nilai korelasi lebih besar dari 0,60. Hal ini menunjukkan bahwa tidak terjadi multikolinearitas antar variabel independen, atau model regresi ini terbebas dari gejala multikolinearitas. Hasil perhitungan yang diperoleh dari SPSS menunjukkan nilai d (Durbin Waston) sebesar 1,868. Nilai tersebut akan dibandingkan dengan nilai tabel signifikansi 0,05 (5\%), dengan jumlah responden adalah 100 ( $\mathrm{T}=100)$, dan jumlah variabel independen adalah $2(\mathrm{~K}=2)$. Nilai dL (batas bawah durbin waston) dan dU (batas atas durbin waston) sebesar dL = 1, 65404 dan $\mathrm{dU}=1$, 69439. Dari data ini, dapat disimpulkan bahwa tidak terdapat autokorelasi atau tidak ada korelasi antara pengamatan dan data observasi sebelumnya, karena nilai $\mathrm{d}=1,868>\mathrm{dU}=1,69439$.

Koefisien determinasi ( $R$ Square) sebesar 0,506 menujukkan kontribusi variabel lokasi usaha dan fasilitas pelayanan terhadap variasi keputusan pembelian sebesar 50,6 \%. Sedangkan faktor lainnya diluar model penelitian sebesar 49, 4 \%. Peneliti mencatat bahwa faktor lain tersebut seperti nilai emosional, nilai sosial, nilai kualitas, and nilai fungsional. 


\section{Pengaruh Lokasi terhadap Keputusan Menginap}

Berdasarkan perhitungan SPSS, diperoleh nilai koefisien regresi antara lokasi dengan keputusan menginap sebesar 0,361 dengan nilai Sig P sebesar $0.000, \mathrm{t}$ hitung sebesar 3,816 dan $t$ tabel sebesar 1,984. Dengan demikian hipotesis yang menyatakan bahwa lokasi usaha/hotel berpengaruh signifikan terhadap keputusan menginap dapat diterima. Penelitian ini membuktikan bahwa lokasi berpengaruh terhadap keputusan menginap. Lokasi mengacu pada berbagai aktivitas pemasaran yang berusaha memperlancar dan mempermudah penyampaian atau penyaluran barang dan jasa dari produsen kepada konsumen. Lokasu yang strategis dan mudah dijangkau sangat diperlukan oleh konsumen, sehingga konsumen dapat melakukan aktifitasnya dengan mudah dan lancar.. Dan hasil penelitian ini relevan dengan penelitian yang dikemukakan oleh Wismaya, Telagawathi, and Suarmanayasa (2017) dan penelitian Syahputra and Herman (2020) menunjukkan bahwa terdapat pengaruh yang signifikan secara parsial terhadap keputusan menginap.

\section{Pengaruh Fasilitas terhadap Keputusan Menginap}

Berdasarkan perhitungan SPSS diperoleh nilai koefisien regresi antara fasilitas dengan keputusan menginap sebesar 0,392, $t$ hitung $=4,200$ dan Sig P 0.000 yang menunjukkan terdapat pengaruh positif antara fasilitas dengan keputusan menginap. Dengan demikian hipotesis yang menyatakan bahwa fasilitas secara parsial berpengaruh signifikan terhadap keputusan menginap dapat diterima.

Penelitian ini membuktikan bahwa Fasilitas terbukti berpengaruh terhadap keputusan menginap Hasil penelitian ini sejalan dengan yang dikemukakan oleh Syahputra and Herman (2020), fasilitas adalah segala sesuatu yang berupa benda maupun uang yang dapat memudahkan serta memperlancar pelaksanaan suatu usaha tertentu. Maka dengan tersedianya segala fasilitas yang dapat menunjang segala kebutuhan dan harapan konsumen akan menciptakan suatu keputusan tertentu. Hasil penelitian ini relevan dengan penelitian yang dikemukakan oleh Dan hasil penelitian ini relevan dengan penelitian yang dikemukakan oleh Jusuf et al. (2018)menunjukkan bahwa terdapat pengaruh yang signifikan secara parsial terhadap keputusan menginap dengan di perkuat dengan hasil penelitian yang dilakukan oleh Lempoy et al. (2015).

\section{KESIMPULAN DAN SARAN}

Berdasarkan hasil penelitian dan pembahasan, maka dapat dibuat kesimpulan sebagai berikut: (1) Penentuan lokasi menginap merupakan bagian yang sangat penting bagi seseorang untuk tinggal. Di sisi lain akses jalan, alat transportasi yang tersedia, dan lokasi hotel yang terjangkau akan memudahkan seseorang untuk melakukan mobilitas dari dan menuju ke hotel. Hal ini terbukti dengan penelitian yang sudah dilakukan bahwa konsumen yang menginap dapat dengan mudah menemukan dan mengetahui lokasi Hotel Asri Tasikmalaya.

Fasilitas merupakan unsur pendukung bagi seseorang untuk menentukan suatu pilihan untuk menginap. Ketersediaan berbagai fasilitas yang dapat memenuhi 
kebutuhan seseorang yang akan menjadikan nilai tambah untuk memberikan keputusan. Hal ini terbukti dengan penelitian yang sudah dilakukan bahwa konsumen yang menginap di Hotel Asri Tasikmalaya telah terpenuhi kebutuhannya dengan baik.

Untuk mencapai suatu keputusan untuk menginap akan menjadi proses yang sederhana maupun kompleks, dalam hal ini peranan dari lokasi dan fasilitas sangatlah penting dan berpengaruh terhadap keputusan yang akan dibentuk. Dimana lokasi dan fasilitas hotel yang sesuai dapat membentuk seseorang untuk menentukan suatu pilihan. Berdasarkan hasil penelitian dapat disimpulkan bahwa lokasi dan fasilitas berpengaruh signifikan secara parsial terhadap keputusan menginap di Hotel Asri Tasikmalaya. Berdasarkan hasil penelitian dapat disimpulkan bahwa lokasi dan fasilitas berpengaruh signifikan secara simultan terhadap keputusan menginap di Hotel Asri Tasikmalaya.

Berdasarkan kesimpulan diatas, saran- saran yang diharapkan dapat membantu perusahaan dan bermanfaat baik bagi perusahaan adalah : (1) Hotel Asri Tasikmalaya diharapkan dapat menambah sarana dan fasilitas pendukung untuk menjangkau lokasi hotel, sehingga tamu lebih tertarik menginap di Hotel Asri Tasikmalaya seperti penambahan petunjuk arah, layanan antar jemput. (2) Hotel Asri Tasikmalaya diharapkan dapat memperbaiki fasilitas hotel seperti menambah jumlah kamar hotel, meningkatkan fasilitas penunjang olahraga atau fasilitas didalam kamar hotel, dan penyajian makanan yang lebih bervariasi.

\section{DAFTAR PUSTAKA}

Agoda. Hotel Asri Plaza Asia Tasikmalaya Retrieved 8 November, 2020, from https://www.agoda.com/id-id/hotel-asri-plaza-asia-tasikmalaya/hotel/ tasikmalaya-id.html?cid=1844104

Benke, B. (2020). Pariwisata, Sektor Pertama dan Paling Terdampak Pandemi Covid-19 Retrieved 6 November, 2020, from https://www.suaramerdeka.com/news/ nasional/228038-pariwisata-sektor-pertama-dan-paling-terdampak-pandemicovid-19

Booking.com. Hotel Asri Tasikmalaya Retrieved 8 November 2020, 2020, from https://www.booking.com/hotel/id/asri-tasikmalaya.id.html

BPS. (2020). ingkat Penghunian Kamar pada Hotel Bintang di Indonesia, 2008 - 2020. Retrieved 4 November 2020, from Biro Pusat Statistik https://www.bps.go.id/ linkTableDinamis/view/id/980

Caesari, S., Nugraha, H. S., \& Prabawani, B. (2015). Analisis Faktor - Faktor yang Mempengaruhi Konsumen Untuk Menginap di Hotel Puri Saron. Diponegoro Journal Of Social And Political Of Science 1-11.

Chandra, S. M., \& Tielung, M. V. J. (2015). Pengaruh Kualitas Pelayanan, Promosi, Dan Lokasi Terhadap Keputusan Konsumen Menggunakan Hotel Baliem Pilamo Di Wamena. Jurnal EMBA 3(3), 959-970. 
Duli, N. (2019). Metode Penelitian Kuantitatif: Beberapa Konsep Dasar untuk Penulisan Skripsi \& Analisis Data dengan SPSS. Yogyakarta: Penerbit Deeppublish.

Fauzan, M., \& Setiyorini, H. P. D. (2011). Upaya Meningkatkan Keputusan Penggunaan Meeting Package Di Hotel Bumi Asih Jaya Bandung Melalui Demand Based Pricing Methods: Survei pada Tamu Wisatawan Bisnis Pengambil Keputusan Penggunaan Meeting Package Di Hotel Bumi Asih Jaya Bandung. Tourism and Hospitality Essentials (THE) Journal, 1(2), 101-119.

Juhari. (2016). Analisis Harga Terhadap Room Occupancy Hotel Dan Penginapan Di Kota Pangkalpinang. Jurnal Bisnis Darmajaya, 02(02), 1-12.

Jusuf, I. S. H., Laela, \& Sari, F. N. (2018). Pengaruh Periklanan Dan Fasilitas Terhadap Keputusan Menginap Di Hotel Grand Dafam Bela Ternate. Jurnal Manajemen Sinergi (JMS), 5(2).

Kotler, P., \& Amstrong, G. (2013). Prinsip-prinsip Pemasaran (Edisi 12 ed.). Jakarta: Penerbit Erlangga.

Kotler, P., \& Keller, K. L. (2012). Marketing Management (14 ed.): Pearson.

Lempoy, N. C., Mandey, S. L., \& Loindong, S. S. R. (2015). Pengaruh Harga, Lokasi, Dan Fasilitas Terhadap Keputusan Menggunakan Jasa Taman Wisata Toar Lumimuut (Taman Eman) Sonder. Jurnal EMBA 3(1), 1072-1083.

Memah, D., Tumbel, A., \& Rate, P. V. (2015). Analisis Strategi Promosi, Harga, Lokasi, Dan Fasilitas Terhadap Keputusan Pembelian Rumah Di Citraland Manado. Jurnal EMBA, 3(1).

Pegipegi. Hotel Asri Tasikmalaya Retrieved 8 November, 2020, from https:// www.pegipegi.com/hotel/tasikmalaya/hotel_asri_tasikmalaya_913695/

Permatasari, R. M., \& Hadi, M. (2017). Pengaruh Kualitas Pelayanan, Fasilitas, Dan Lokasi Terhadap Keputusan Menggunakan Jasa Di Puskesmas Turen-Malang. J A B Jurnal Aplikasi Bisnis, 3(1).

Supriyanto, M., \& Taali, M. (2018). Pengaruh Bauran Pemasaran (Marketing Mix) Terhadap Pengambilan Keputusan Menginap Di The Sun Hotel Madiun. Epicheirisi, 2(1), 13-21.

Syahputra, R. R., \& Herman, H. (2020). Pengaruh Promosi Dan Fasilitas Terhadap Keputusan Menginap Di Os Hotel Batam. Jurnal Ilmiah Kohesi, 4(3).

Tjiptono, F. (2014). Pemasaran Jasa - Prinsip, Penerapan, dan Penelitian. Yogyakarta: Andi Offset. 
Traveloka. Hotel Asri Tasikmalaya Retrieved 8 November, 2020, from https:// www.traveloka.com/id-id/hotel/indonesia/hotel-asri-tasikmalaya$\underline{3000010021447}$

Wismaya, K. W. B., Telagawathi, N. L. W. S., \& Suarmanayasa, I. N. (2017). Pengaruh Kualitas Pelayanan Dan Fasilitas Serta Lokasi Terhadap Keputusan Menginap Di New Garuda Hotel Singaraja. Jurnal Manajemen Indonesia, 8(2). 